\title{
MEAN LEVEL OF DEPRESSION AMONG THE ELDERLY BASED ON EACH INDICATOR OF GERIATRIC DEPRESSION SCALE ( GDS ) INSTRUMENT IN SELECTED SOCIAL INSTITUTION YOGYAKARTA INDONESIA
}

\author{
Endang Nurul Syafitri \\ Faculty of Health Sciences \\ University of Respati Yogyakarta \\ Email : endang.ns85@gmail.com
}

\begin{abstract}
Introduction : Population around the world are rapidly aging, the increasing number of elderly in the world is expected to be a new problem for world health. Aging presents both challenges and opportunities. In this aging process, several changes concerning the biological, psychological, social and spiritual aspects, is expected to occur. Indonesia has entered the country as well as the provisions of the old population structure of the world body because of the increased number of erderly people that almost reached more than 7 percent. The purpose of this research was to determine Mean Level of Depression among the Elderly based on each indicator of GDS Instrument. Methods : This study descriptive analyzed, quantitative methode. The number of research samples was 60 elderly. Data unvaried analyzed to each indicator Depression of modifications GDS Instrrument. Results : Level of each indicators of modifications Geriatrics Depression Scale (GDS) that is Physical aspect obtained the general weighted mean of 2.86 with verbal interpretation moderate level, Psychological aspect got the general weighted mean of 2.95 with verbal interpretation of moderate level and Social aspect got the general weighted mean of 2.92 with verbal interpretation of moderate level. Conclusions : Clients who are experiencing depression becomes helpless because of loss of energy, Hopelessness and problem of interaction with environment such as family members and friends.
\end{abstract}

Keywords: Elderly, Depressed, Geriatric Depression Scale

\section{INTRODUCTION}

Population around the world are rapidly aging, the increasing number of elderly in the world is expected to be a new problem for world health. Aging presents both challenges and opportunities. It strains pension and social security systems, increase demand for acute and primary health care, requires larger and better trained health workforce and increase the need for long term care (Irawan, 2013). There is a demand to ensure the quality of elderly social welfare so that they will not experience serious problems and remain productive. Indonesia has entered the country as well as the provisions of the old population structure of the world body because of the increased number of elderly people that almost reached more than 7 percent. Indonesia ranked fourth in the world for having the bigger number of elders next to China, India and Japan (U.S. Census Bureau, International Data Base, 2009).
Changes in the body system in the elderly is due to the aging process resulting to decreased ability of the elders for physical activity and changes in their physical appearance affect the elder's social and economic life (Pangastuti et al, 2019). This situation is a stressor that can lead to negative feelings for the elderly that is having the feeling of helplessness, uselessness, frustration, despair, sadness and feelings of isolation, that often cause and lead to their minimal interactions with others on total withdrawal from others.

In addition to biological changes, aging process has an impact on the psychological changes among elderly. Psychological changes are closely related to biological changes that might occur. A change in the biological or physical has an impact on the ability of sensation, perception and psychomotor performances which are extremely important in performing the activities of daily living among 
elders (Atchley \& Barusch, 2009). This functioning decreases the effect on

The existence of a serious physical illness in particular with regard to the brain as well as those living in a special place such as social institutions can lead to the elderly experiencing behavioral changes (Ebersole, et al., 2008). Change in behavior relates to emotional feelings of sadness, fear, anger, frustration, guilt, feeling helpless and useless (Judha, \& Syafitri, 2018). This change is an indicator of psychosocial problems in the elders. In addition to the biological and psychological changes, the aging process can also affect the social life of the elderly (Pratiwi, 2018).

Social changes experienced by the elderly affects their status and role performances within the group or community, loss of support system by the family, friends and neighbors (Ebersole, et al., 2008). In additions to physical and psychological problems there are some factors that may affect the mental health of elders. Financial problems can also be stressors for the elders.

In Indonesia lot of the elders, are staying in Social Institutions because they feel that they are being neglected by their immediate family members, friends and relatives. These are the elders who at present are experiencing signs and symptoms of depression may be because of loss of social support system, economic, adequacies in life style and many more. Depression among the elderly may worsen if this situation is not addressed properly.

Based on the results of a preliminary study conducted by researchers at the Social Institution in Yogyakarta, they found out that among the twenty (20) elderly people who were interviewed sixty percent $(60 \%)$ of the elderly experienced depression with symptoms of feeling helpless, useless, lonely, and lazy to follow the activity and do not socialize with other seniors. Observation revealed of that most of the elderly people are left alone in their homes with no opportunities to do any activity and communicate with others. This phenomenon was supported by the background of the elderly, who live in this social institution which is $90 \%$ and with the background of being displaced. This research was to determine Mean Level of Depression among the Elderly based on each indicator of GDS Instrument.

\section{METHODS}

This study was participated by 60 depressed elderly in Social Institution in Yogyakarta. A Self-made survey questionnaire was formulated and utilized by the researcher. This instrument is a scale measuring depression in the elderly (Geriatric Depression Scale / GDS). Scale GDS constitutes a measuring tool for depression among elderlies that is both universal and is more accurate than the measuring tools (Ebersole, et al., 2008). The instrument used was a 20 item questionnaire. The 15 items were derived from the GDS and 5 were formulated by the researcher. Validation of the research instrument was done in consultation with three expert psychiatric nurses. Pilot testing was conducted to assess the validity and reliability of the survey tool utilizing the Cronbach Alpha method. The value of the reliability-Cronbach's alpha-coefficient is 0.877 , indicating that the instrument is highly reliable. The data collected were computed utilizing the following statistical tools Weighted mean was used to measure the depression level of the respondents.

\section{RESULTS}

The tables 1 show the mean level of the elderly respondents. The assessment taken from the total number of questions answered by the respondents included on about Physical, Psychological, and Social aspects.

Table 1. Mean Level of Depression among the Elderly Respondents in Terms of Physical Aspect

Indicators

Are most of the time you no longer have a good spirit?
Mean

Interpretation

2.73 Moderate Level 


\section{Indicators}

Do you often feel helpless?

Do you feel you have more problems with memory than most?

Do you often feel tired?

Has your appetite changed? (decreased or excess)

Is your sleep disturbed? (Excessive or less)

General Weighted Mean
Mean Interpretation

2.26

3.13

2.96

3.13

2.96

2.86
Low Level

Moderate Level

Moderate Level

Moderate Level

Moderate Level

Moderate Level

4.0-3.28 (High Level); 3.27-2.52 (Moderate Level); 2.51-1.76 (Low Level); 1.75-1.0 (Not Depressed)

In Table 1, Physical aspect obtained the general weighted mean of 2.86 with verbal interpretation moderate level. Statement number 3 and 5 in the experimental group got the highest mean of 3.13 with verbal interpretation of moderate level of depression and statement no. 4 got the lowest mean of 2.26 with verbal interpretation of low level of depression which further explains that clients who are experiencing depression becomes helpless because of loss of energy.

Table 2. Mean Level of Depression among the Elderly Respondents in Terms of Psychological Aspect

\begin{tabular}{llc}
\hline \multicolumn{1}{c}{ Indicators } & Mean & Interpretation \\
Do you no longer feel satisfaction in your life? & 2.96 & Moderate Level \\
Do you feel that your life is empty? & 2.83 & Moderate Level \\
Are you afraid that something bad is going to happen to you? & 2.96 & Moderate Level \\
Are you irritable and easily angered? & 2.96 & Moderate Level \\
Do you feel that your situation is hopeless? & 3.26 & Moderate Level \\
Do you think that most people are better off than you are? & 2.83 & Moderate Level \\
Do you feel worthless? & 3.13 & Moderate Level \\
Do you often feel sad? & 2.73 & Moderate Level \\
General Weighted Mean & 2.95 & Moderate Level \\
\hline
\end{tabular}

4.0-3.28 (High Level); 3.27-2.52 (Moderate Level); 2.51-1.76 (Low Level); 1.75-1.0 (Not Depressed)

In table 2, Psychological aspect got the general weighted mean of 2.95 with verbal interpretation of moderate level. Statement no. 11 in the experimental group got the highest mean of 3.26 and statement no. 14 got the lowest mean of 2.73 with both verbal interpretation of moderate level of depression. Result further explain that clients who are experiencing love to compare themselves with others, the others are more successful, smart, lucky, wealthy, more educated, more experienced, more attention and other negative thoughts.

\section{Table 3. Mean Level of Depression among the Elderly Respondents in Terms of Social Aspect}




\section{Indicators}

Have you dropped many of your activities and interests?

Do you often feel bored when gathered together with other people?

Do you prefer to stay at home, rather than going out and doing new things?

Do you feel inferior and ashamed to meet with other people?

Do you feel difficult to establish relationships with other people?

Do you prefer to own rather than to talk to other people?
Mean Interpretation
3.26 Moderate Level
3.13 Moderate Level
2.83 Moderate Level
2.86 Moderate Level
2.73 Moderate Level
2.73 Moderate Level
$2.92 \quad$ Moderate Level

General Weighted Mean

4.0-3.28 (High Level); 3.27-2.52 (Moderate Level); 2.51-1.76 (Low Level); 1.75-1.0 (Not Depressed)

In Table 3, Social aspect got the general weighted mean of 2.92 with verbal interpretation of moderate level. Statement no. 15 in the experimental group got the highest mean of 3.26 and statement nos. 19 and 20 got the lowest mean of 2.73 with both verbal interpretation of moderate level of depression which further explains that clients who are experiencing social problems that occur normally revolve around the problem of interaction with environment such as family members and friends.

\section{DISCUSSIONS}

The results of this study, Physical aspect obtained the general weighted mean of 2.86 with verbal interpretation moderate level. Statement number 3 and 5 in the experimental group got the highest mean of 3.13 with verbal interpretation of moderate level of depression and statement no. 4 got the lowest mean of 2.26 with verbal interpretation of low level of depression which further explains that clients who are experiencing depression becomes helpless because of loss of energy. Depression is a feeling of sadness, helplessness, and pessimism associated with an affliction, it is also a psychiatric disorder in form of natural feeling such as affective, and mood disorder characterized by moodiness, lethargy of passion, feeling useless, and hopelessness, Pieter and Lopez (2010). Physical symptoms that can be found in individuals with depression include: Impaired sleep patterns (difficulty sleeping, too much or too little). The reduced level of activity, in general, people with depression showed a passive behavior, like activities that do not involve others such as watching television, eating and sleeping. Depressed individuals easily gets tired and exhausted but able to participate / perform on entire function of the person in all his/her endeavor.

Psychological aspect got the general weighted mean of 2.95 with verbal interpretation of moderate level. Statement no. 11 in the experimental group got the highest mean of 3.26 and statement no. 14 got the lowest mean of 2.73 with both verbal interpretation of moderate level of depression. Result further explain that clients who are experiencing love to compare themselves with others, the others are more successful, smart, lucky, wealthy, more educated, more experienced, more attention and other negative thoughts. Psychologically according to Miller (2009) depression in the elderly can lead to feelings of anxiety, irritable, decreased self-esteem, no sense or feeling empty and negative feelings about themselves. The psychological symptoms that can be found in individuals who experience depression are: loss of self-esteem, depressed individuals tend to see things in a negative light, including hopelessness. Depressed people feel useless and 
this feeling arises because the individual also feels he/she is a failure, especially in one's field of especialization. Individuals perceive an event that happened to him as a punishment or a consequence of his failure. The feeling of guilt and being overwhelmed are usual occurrence for depressed people.

Social aspect in the experimental group got the general weighted mean of 2.92 with verbal interpretation of moderate level. Statement no. 15 in the experimental group got the highest mean of 3.26 and statement nos. 19 and 20 got the lowest mean of 2.73 with both verbal interpretation of moderate level of depression which further explains that clients who are experiencing social problems that occur normally revolve around the problem of interaction with environment such as family members and friends. This problem is not only in conflict, but there are also other problems like feeling of inferiority, shame, anxiety if it is among the group and feel comfortable to be open and actively establish relationship with the environment even if there is a chance (Lubis, 2010). Social problems that occur in an individual normally revolve around the problem of interaction with environment such as family members, friends, co-workers, superiors or subordinates. This problem is not only in conflict, but also other problems as well as feelings of inferiority, shame, anxiety of being in and among the group and feeling uncomfortable to be open and less intention to establish relationship with the environment even if there is a chance. This phenomenon is in accordance with the material questions in the GDS like feeling dissatisfied, unhappy, feeling empty and hopeless, feeling excited, decreased activity, feeling helpless, feeling the energy and presence of mind of other people are better.

\section{CONCLUSIONS}

Clients who are experiencing depression becomes helpless because of loss of energy, Hopelessness and problem of interaction with environment such as family members and friends.

\section{REFERENCES}

Atchley, R.C. dan Barusch, A.S. (2009). Social forces and aging; an introduction to social gerontology. (12th ed.). USA: Thomson Learning, Inc.

Azizah, L. M. (2011). Keperawatan Lanjut Usia. Yogyakarta: Graha Ilmu.

Bandiyah, S. (2009). Lanjut Usia dan Keperawatan Gerontik. Yogyakarta: Nuha Medika.

BPKP Republik Indonesia. (1998). Undangundang Republik Indonesia nomor 13 tahun 1998 tentang kesejahteraan lanjut usia. Retrieved Mey 25, 2013 from http://www.bpkp.go.id/unit/hukum/uu/1 998/13-98.pdf.

Ebersole, P., et al., (2008). Gerontological nursing and health aging, (3nd ed.). USA,Philadelphia : Mosby, Inc.

Frisch, N.C. dan Frisch, L.E., (2011). Psychiatric mental health nursing. (4rd ed.). Canada: Thomson Delmar Learning.

Indonesian Census Bureau (2010). Elderly Profile. Retrieved July 13, 2013 from http://menegpp.go.id/V2/index.php/data daninformasi/kependudukan

Indonesian Health Data Profile (2011). Jumlah Lansia di Dunia Semakin Meningkat. Retrieved July 13, 2013 from: http://atjehpost.com/read/2012/09/10/20 567/0/51

Irawan, H. (2013). Gangguan depresi pada lanjut usia. Cermin Dunia Kedokteran, 40(11), 815-819.

Judha, M., \& Syafitri, E. N. (2018). Efektivitas Pemberian Aromaterapi Lemon Terhadap Kecemasan Pada Lansia Di Unit Pelayanan Lanjut Usia Budi Dharma, Umbulharjo Yogyakarta. Jurnal Keperawatan Respati Yogyakarta, 5, 29-33.

Maryam, R., Ekasari, M. F., \& dkk. (2008). Mengenal Usia Lanjut dan Perawatannya. Jakarta Selatan: Salemba Medika.

Miller, C.A. (2004). Nursing for wellness in older adults; theory and practice. USA: 
Lippincott Williams \& Wilkins.

Muhammad, N. (2010). 100 Tanya-Jawab Kesehatan Harian Untuk Lansia. Yogyakarta: Tunas Publishing.

Notoatmodjo, S. (2010). Pendidikan dan perilaku kesehatan. Jakarta: PT Rineka Cipta.

Nugroho, H. (2008). Keperawatan Gerontik \& Geriatrik. Jakarta: Penerbit Buku Kedokteran EGC.

Pangastuti, H. S., Perdana, M., Wati, D. A., Melati, H. I. T., \& Latifah, R. (2019). The Difference of Sodium Intake, Physical Activities and Psychological Problems of Patients Suffering from Hypertension in Rural and Urban Areas. Indonesian Nursing Journal Of Education And Clinic (INJEC), 3(1), 7178.

Pieter, H. Z., \& Lubis, N. L. (2010). Pengantar Psikologi Dalam Keperawatan.
Rawamangun Jakarta: Kencana Prenada Group.

Pratiwi, A. (2018). Cognitive Therapy Group Dynamics Model For Reducing The Level Of Depressed Patients In Mental Hospital. Indonesian Nursing Journal Of Education And Clinic (INJEC), 1(2), 131-133.

Shives, L.R., (2008). Basic concepts of psychiatric mental health nursing. $\left(7^{\text {th }}\right.$ ed.). USA: Lippincott Williams \& Wilkins.

Stuart, G. W. \& Laraia, M.T. (2009). Principle and practice of psychiatric nursing. (9th ed.). Philadelphia, USA: Mosby, Inc.

Tamher. S. dan Noorkasiani. (2009). Kesehatan usia lanjut dengan pendekatan asuhan keperawatan. Jakarta : Salemba medika

Videbeck. (2008). Psuchiatric Mental Health Nursing. Lippincott Williams and Wilkins. 